\section{Career Skills: Our Process and Where We Are Today}

\author{
Dennis T. Ray ${ }^{1}$, Joy J. Winzerling, and Michael E. Staten
}

ADDITIONAL INDEX WORDs. communication skills, critical thinking, problem solving, leadership skills, management skills, soft skills

SUMMARY. Feedback from employers, internship supervisors, and graduate schools tells us that we are doing a good job of teaching students academically/technically, but our graduates require greater training in communications, critical thinking/ problem solving, and leadership/management. Because of their long-term importance to our graduates, we call these "career skills." To address this issue a task force was established, and over a 2-year period, this group defined the College of Agriculture and Life Sciences [CALS (University of Arizona, Tucson)] Students Career Skills Competencies and vetted them through college faculty and more than 50 companies. We divided the CALS Student Career Skills Competencies into three categories: 1) communication skills, 2) critical thinking/problem solving skills, and 3 ) leadership/management skills. We are currently asking each degree-granting unit in the college how they do, or will, incorporate these competencies into their curricula, with the idea of incorporating the competencies into existing courses first, to avoid increasing the number of required credit hours for graduation and time to degree. Our goal is that by graduation, each student should have had multiple opportunities to hone each of these competencies.

$\mathrm{G}$ raduates from the CALS at the University of Arizona are technically competent, but insufficiently prepared in some important broader skills required for career success. This has been the feedback from employers (including government and nongovernmental organizations), internship supervisors, and graduate programs and is common across American higher education as reported by ChamorroPremuzic et al. (2010), Evers et al. (1998), and Grugulis and Vincent (2009). This feedback tells us that we are doing well at training our students technically, but our graduates require more training in communications, critical thinking/problem solving, and leadership/management to be competitive in the job market. Matteson et al. (2016) noted that in the literature these skill sets are called "people skills," "human skills," "interpersonal skills," "teamwork skills," "management skills," and most often "soft skills." Because

College of Agriculture and Life Sciences, University of Arizona, P.O. Box 210036, Tucson, AZ 85721

This article was part of the workshop "Developing Soft Skills in Tomorrow's Leaders" held 10 Aug. 2016, during the ASHS Annual Conference, Atlanta, GA, and sponsored by the ASHS Teaching Methods Working Group

${ }^{1}$ Corresponding author. E-mail: dtray@email.arizona. edu.

doi: 10.21273/HORTTECH03671-17 of their long-term importance to each student's employment options and career success, we refer to them as "career skills."

The concept of career skill development is not new to higher education and accrediting agencies. For example, the American Society for Engineering Education and the Accreditation Council for Graduate Medical Education have encouraged it for quite some time (Zhang, 2012). These skills are important, but not the emphasis of curricula. Our curricula already have the maximum number of courses to fill a 4-year program covering the technical skills required for an academic field. Requiring additional courses to cover career skills is not the answer given the rapid escalation in the cost of tuition and associated pressures to reduce the time to complete a degree.

There is no widely accepted set of career skills (Hurrell et al., 2012). For instance, Robles (2012), ranked (from most important to least important): integrity, communication, courtesy, responsibility, interpersonal skills, professionalism, positive attiwork ethic. Grugulis and Vincent (2009) list: communication, problem solving, teamwork, and ability to improve personal learning and performance, motivation, judgement, leadership, and initiative. tude, teamwork skills, flexibility, and

\section{Methods}

CALS established a Task Force charged to 1) identify the career skills all CALS graduates should possess and 2) define competency levels for each of these skills. Our college is very diverse, with academic programs ranging from the social sciences to the hard sciences, in very basic, applied, and translational areas. After much discussion, we decided to focus on 1 ) communication, 2) critical thinking/problem solving, and 3 ) leadership/management skills for all CALS graduates. Task Force membership included administrators, faculty, and staff: Doug Reed, Cochair (Animal and Comparative Biomedical Sciences), Michael Staten, Cochair (Norton School of Family and Consumer Sciences), Kenneth Feldmann (School of Plant Sciences), Kelly Jackson (Nutritional Sciences), Robert MacArthur (CALS Communications Technologies), Elaine Marchello (Career and Academic Services), Stuart Marsh (School of Natural Resources and the Environment), Dennis Ray (School of Plant Sciences), Kyle Sharp (Career and Academic Services), and Robert Torres (Agricultural Education).

A skill is something that "develops over time, with practice...." (Hurrell et al., 2012), and implies a level of quality, as well as contains an element of action. Thus, development of skills requires a knowledge set, the opportunity to practice the actions, and to obtain feedback on those actions (Matteson et al., 2016). We defined a skill as a talent or ability that comes from training or practice, with the goal of incorporating career skills into our curricula to provide multiple opportunities for students to develop and improve these important skills.

Once we identified and defined the desired career skills for all CALS graduates, the next question was how to measure them. Often these measurements are self-report surveys (Chamorro-Premuzic et al., 2010; Evers et al., 1998; Matteson et al., 2016). However, we wanted measures built directly into our curricula. To do this, we defined competency levels for each career skill. Defining the competency levels helped in several ways: 1) it gave instructors a basic rubric to evaluate individual student 
performance, 2) helped instructors decide at what level they were presently incorporating career skills in their courses, and 3 ) encouraged instructors to include career skills in their courses.

The CALS Task Force developed a first draft of CALS Student Career Skills Competencies. This included defining competence levels for each skill; unacceptable, exit, and advanced levels, with the exit level being the target for our graduates. These competencies were vetted by all CALS faculty and more than 50 companies. The feedback received from this process was discussed, evaluated, and incorporated into a revised set of CALS Student Career Skills Competencies (Tables 1-6).

The Task Force worked over a 2-year period (2014-15), after which the CALS Curriculum and Assessment Committee continued to compile information and to develop support activities to help faculty implement the recommendations and evaluate competency levels. To inform all CALS administrators, faculty, staff, and students, the Office of Career and Academic Services publicized the process and the new CALS Student Career Skills Competencies, and process of evaluation.

At this time, each degree-granting unit in the college is identifying current courses that give students opportunities to develop these career skills and evaluate the level of competency. The CALS Curriculum and Assessment Committee will next work on helping instructors to include career skill objectives into their syllabi alongside existing course goals and learning outcomes. Students should understand not only what career skills are included in a course, but also how their performance is evaluated by including a description of the targeted level of competency.

\section{Discussion}

Our approach/process puts the training of our students in career skills where it should be, with the faculty. Many faculty have included career skills in their courses for some time, often without consciously categorizing them as such. By systematically identifying where in a curriculum we find career skills, we can identify gaps and assure coverage of all the competencies, and that students have multiple opportunities to hone each skill. By incorporating career skills into existing courses, rather than building

Table 1. The University of Arizona College of Agriculture and Life Sciences [CALS (Tucson, AZ)] identified communication competencies "career skills" to incorporate into the CALS curriculum. The rubric identifies specific skills and competency levels to evaluate student proficiency in written and electronic skills.

\begin{tabular}{|c|c|c|c|}
\hline \multirow[b]{2}{*}{ Career skills } & \multicolumn{3}{|c|}{ Competency level } \\
\hline & Unacceptable & Exit & Advanced \\
\hline $\begin{array}{l}\text { Use correct grammar and } \\
\text { structure sentences/ } \\
\text { paragraphs in logical } \\
\text { progression to provide } \\
\text { insights, make a point, or } \\
\text { support a position }\end{array}$ & $\begin{array}{l}\text { Demonstrates logical } \\
\text { order, but uses poor } \\
\text { sentence structure and } \\
\text { grammar }\end{array}$ & $\begin{array}{l}\text { Demonstrates ability to } \\
\text { write a logical } \\
\text { document providing } \\
\text { insights with } \\
\text { predominantly correct } \\
\text { grammar }\end{array}$ & $\begin{array}{l}\text { Writes a professional } \\
\text { persuasive argument } \\
\text { with terminology } \\
\text { appropriate for their } \\
\text { target audience } \\
\text { without grammatical } \\
\text { errors }\end{array}$ \\
\hline $\begin{array}{l}\text { Compose professional written } \\
\text { communications that provide } \\
\text { insights and steps needed by } \\
\text { others in a variety of formats }\end{array}$ & $\begin{array}{l}\text { Written communication } \\
\text { is vague, unfocused, or } \\
\text { lacks logical order }\end{array}$ & $\begin{array}{l}\text { Conveys written context } \\
\text { and details in proper } \\
\text { and logical format }\end{array}$ & $\begin{array}{l}\text { Provides succinct logical } \\
\text { information written in } \\
\text { a professional manner }\end{array}$ \\
\hline $\begin{array}{l}\text { Identify and distill key points to } \\
\text { compress a longer document } \\
\text { into a summary }\end{array}$ & $\begin{array}{l}\text { Fails to communicate } \\
\text { only the essential } \\
\text { points and provides } \\
\text { too much detail for the } \\
\text { summary's intended } \\
\text { audience }\end{array}$ & $\begin{array}{l}\text { Focuses on the essential } \\
\text { details and keeps } \\
\text { audience in mind when } \\
\text { summarizing }\end{array}$ & $\begin{array}{l}\text { Provides a succinct and } \\
\text { complete summary } \\
\text { with appropriate detail } \\
\text { and references to } \\
\text { quickly navigate the } \\
\text { original document }\end{array}$ \\
\hline $\begin{array}{l}\text { Develop appropriate visual } \\
\text { images that support verbal } \\
\text { communications and graphs, } \\
\text { charts, infographics, photos, } \\
\text { video clips, and original } \\
\text { videos }\end{array}$ & $\begin{array}{l}\text { Visuals are verbose and/ } \\
\text { or hard to read; } \\
\text { distract and/or } \\
\text { confuse the audience } \\
\text { more than inform }\end{array}$ & $\begin{array}{l}\text { Visuals are appealing, } \\
\text { legible, and assist in } \\
\text { the delivery of the } \\
\text { message to the target } \\
\text { audience }\end{array}$ & $\begin{array}{l}\text { Visuals reflect deep } \\
\text { understanding of the } \\
\text { topic and creativity in } \\
\text { reinforcing and } \\
\text { supplementing key } \\
\text { points for the audience }\end{array}$ \\
\hline $\begin{array}{l}\text { Compose professional posts for } \\
\text { social media }\end{array}$ & $\begin{array}{l}\text { Creates post without } \\
\text { consideration of } \\
\text { medium or audience, } \\
\text { and uses inappropriate } \\
\text { slang and/or poor } \\
\text { grammar }\end{array}$ & $\begin{array}{l}\text { Creates appropriate post } \\
\text { for social medium and } \\
\text { audience that is } \\
\text { consistent with } \\
\text { acceptable norms }\end{array}$ & $\begin{array}{l}\text { Uses appropriate } \\
\text { combination of visuals } \\
\text { and texts to create an } \\
\text { effective post with } \\
\text { appropriate external } \\
\text { references }\end{array}$ \\
\hline
\end{tabular}


Table 2. The University of Arizona College of Agriculture and Life Sciences [CALS (Tucson, AZ)] identified communication competencies "career skills" to incorporate into the CALS curriculum. The rubric identifies specific skills and competency levels to evaluate student proficiency in verbal skills.

\begin{tabular}{|c|c|c|c|}
\hline \multirow[b]{2}{*}{ Career skills } & \multicolumn{3}{|c|}{ Competency level } \\
\hline & Unacceptable & Exit & Advanced \\
\hline $\begin{array}{l}\text { Communicate simple and } \\
\text { complex ideas during } \\
\text { professional meetings, } \\
\text { discussions, and related } \\
\text { environments }\end{array}$ & $\begin{array}{l}\text { Does not engage in the verbal } \\
\text { discussions or, when engaged, } \\
\text { repeats points already made } \\
\text { and/or makes irrelevant } \\
\text { comments }\end{array}$ & $\begin{array}{l}\text { Able to ask questions, } \\
\text { listen, and provide } \\
\text { meaningful and } \\
\text { structured discussion }\end{array}$ & $\begin{array}{l}\text { Offers an insightful perspective and } \\
\text { actively participates without } \\
\text { dominating the discussion, } \\
\text { enriching the experience for all } \\
\text { involved }\end{array}$ \\
\hline $\begin{array}{l}\text { Develop appropriate visual } \\
\text { images that support verbal } \\
\text { communications }\end{array}$ & $\begin{array}{l}\text { Visuals are verbose and/or hard to } \\
\text { read; distract and/or confuse } \\
\text { the audience more than inform }\end{array}$ & $\begin{array}{l}\text { Visuals are appealing, } \\
\text { legible, and assist in } \\
\text { the delivery of the } \\
\text { message to the target } \\
\text { audience }\end{array}$ & $\begin{array}{l}\text { Visuals reflect deep understanding } \\
\text { of the topic and creativity in } \\
\text { reinforcing and supplementing } \\
\text { key points for the audience }\end{array}$ \\
\hline $\begin{array}{l}\text { Listen effectively, engage } \\
\text { others in professional } \\
\text { conversation, and ask } \\
\text { questions to obtain } \\
\text { important information }\end{array}$ & $\begin{array}{l}\text { Demonstrates little interest in the } \\
\text { conversation when others are } \\
\text { speaking, fails to make eye } \\
\text { contact, and/or interrupts } \\
\text { others }\end{array}$ & $\begin{array}{l}\text { Maintains eye contact, } \\
\text { responds appropriately } \\
\text { with comments and } \\
\text { questions, and does } \\
\text { not interrupt }\end{array}$ & $\begin{array}{l}\text { Engages in conversation, reacts } \\
\text { appropriately to nonverbal cues, } \\
\text { and connects sufficiently to } \\
\text { make a positive and memorable } \\
\text { impression }\end{array}$ \\
\hline
\end{tabular}

Table 3. The University of Arizona College of Agriculture and Life Sciences [CALS (Tucson, AZ)] identified communication competencies "career skills" to incorporate into the CALS curriculum. The rubric identifies specific skills and competency levels to evaluate student proficiency in integrated job search skills.

\begin{tabular}{|c|c|c|c|}
\hline \multirow[b]{2}{*}{ Career skills } & \multicolumn{3}{|c|}{ Competency level } \\
\hline & Unacceptable & Exit & Advanced \\
\hline $\begin{array}{l}\text { Prepare documents } \\
\text { for a professional } \\
\text { job search }\end{array}$ & $\begin{array}{l}\text { Student does not have } \\
\text { a professional resume } \\
\text { or cover letter }\end{array}$ & $\begin{array}{l}\text { Has a professional resume and } \\
\text { cover letter which can be } \\
\text { tailored to the position }\end{array}$ & $\begin{array}{l}\text { Resume and cover letter are tailored to } \\
\text { the employer using industry } \\
\text { standard language }\end{array}$ \\
\hline $\begin{array}{l}\text { Engage in a } \\
\text { professional job } \\
\text { search }\end{array}$ & $\begin{array}{l}\text { Bases job selection on pay } \\
\text { alone or the level of } \\
\text { satisfaction anticipated } \\
\text { without conducting } \\
\text { sufficient research }\end{array}$ & $\begin{array}{l}\text { Researches career/job options, } \\
\text { taking into consideration } \\
\text { multiple factors (e.g., } \\
\text { industry stability and position } \\
\text { longevity; opportunities for } \\
\text { advancement) }\end{array}$ & $\begin{array}{l}\text { Has secured internship or other direct } \\
\text { experience with potential } \\
\text { employer(s) }\end{array}$ \\
\hline $\begin{array}{l}\text { Effectively interview } \\
\text { for a job }\end{array}$ & $\begin{array}{l}\text { Does not research or } \\
\text { prepare for the } \\
\text { interview resulting in } \\
\text { poor answers in } \\
\text { interviews and asking } \\
\text { inappropriate } \\
\text { questions of the } \\
\text { interviewer }\end{array}$ & $\begin{array}{l}\text { Researches the employer and } \\
\text { the industry and anticipates } \\
\text { basic interview questions to } \\
\text { prepare appropriate answers. } \\
\text { Understands professional } \\
\text { dress code and conduct for } \\
\text { interviews }\end{array}$ & $\begin{array}{l}\text { Uses appropriate electronic media to } \\
\text { learn about both the employer and } \\
\text { the interviewer, and prepares } \\
\text { questions for the interviewer. } \\
\text { Student practices answering } \\
\text { challenging situational interview } \\
\text { questions with confidence and poise }\end{array}$ \\
\hline $\begin{array}{l}\text { Network effectively } \\
\text { both in-person and } \\
\text { electronically }\end{array}$ & $\begin{array}{l}\text { Fails to approach } \\
\text { strangers in } \\
\text { a professional setting } \\
\text { to engage in } \\
\text { conversation; makes } \\
\text { minimal effort use } \\
\text { networking media }\end{array}$ & $\begin{array}{l}\text { Able to approach and engage } \\
\text { professionals, present self via } \\
\text { a well-crafted "elevator" } \\
\text { speech, and build } \\
\text { a conversation. Has a current } \\
\text { and completed professional } \\
\text { networking profile }\end{array}$ & $\begin{array}{l}\text { Comfortable and confident in any } \\
\text { professional social setting, and } \\
\text { prepared to engage in discussion on } \\
\text { a variety of topics and current } \\
\text { events. Has a complete presence in } \\
\text { terms of social media profiles as well } \\
\text { as professional portfolio or website }\end{array}$ \\
\hline
\end{tabular}


Table 4. The University of Arizona College of Agriculture and Life Sciences [CALS (Tucson, AZ)] identified problem solving/critical thinking competencies "career skills" to incorporate into the CALS curriculum. The rubric identifies specific skills and competency levels to evaluate student proficiency in problem solving/critical thinking skills.

\begin{tabular}{|c|c|c|c|}
\hline \multirow[b]{2}{*}{ Career skills } & \multicolumn{3}{|c|}{ Competency level } \\
\hline & Unacceptable & Exit & Advanced \\
\hline Define the problem & $\begin{array}{l}\text { Unable to define or } \\
\text { demonstrate an } \\
\text { understanding of the } \\
\text { problem }\end{array}$ & $\begin{array}{l}\text { Identify and demonstrate a clear } \\
\text { understanding of the } \\
\text { problem }\end{array}$ & $\begin{array}{l}\text { Clearly identifies the problem } \\
\text { and considers multiple } \\
\text { contributing factors }\end{array}$ \\
\hline $\begin{array}{c}\text { Gather relevant } \\
\text { information }\end{array}$ & $\begin{array}{l}\text { Unable to distinguish } \\
\text { appropriate from } \\
\text { inappropriate sources and } \\
\text { unable to draw assumptions } \\
\text { from incomplete data }\end{array}$ & $\begin{array}{l}\text { Use appropriate sources to } \\
\text { obtain relevant information, } \\
\text { whether complete or } \\
\text { incomplete; make logical } \\
\text { assumptions }\end{array}$ & $\begin{array}{l}\text { Assumptions made are based on } \\
\text { sound deductive reasoning } \\
\text { and extensive review of } \\
\text { relevant information }\end{array}$ \\
\hline Formulating a solution & $\begin{array}{l}\text { No consideration or } \\
\text { recognition of bias or } \\
\text { consequences }\end{array}$ & $\begin{array}{l}\text { Present/consider all sides, } \\
\text { recognize bias, recognize } \\
\text { potential risks and } \\
\text { consequences, and synthesize } \\
\text { a plan }\end{array}$ & $\begin{array}{l}\text { Solution takes into account and } \\
\text { is adjusted for bias, risks, as } \\
\text { well as consequences }\end{array}$ \\
\hline Reflection/evaluation & $\begin{array}{l}\text { Reflection and evaluation rarely } \\
\text { occur and are done in } \\
\text { a superficial manner }\end{array}$ & $\begin{array}{l}\text { Reflection and evaluation } \\
\text { occurs regularly and focus is } \\
\text { given to improvement }\end{array}$ & $\begin{array}{l}\text { During in-depth reflection and } \\
\text { evaluation additional } \\
\text { learnings are discovered and } \\
\text { behaviors altered }\end{array}$ \\
\hline
\end{tabular}

Table 5. The University of Arizona College of Agriculture and Life Sciences [CALS (Tucson, AZ)] identified leadership/ management competencies "career skills" to incorporate into the CALS curriculum. The rubric identifies specific skills and competency levels to evaluate student proficiency in self-management/professionalism skills.

\begin{tabular}{|c|c|c|c|}
\hline \multirow[b]{2}{*}{ Career skills } & \multicolumn{3}{|c|}{ Competency level } \\
\hline & Unacceptable & Exit & Advanced \\
\hline Self-awareness & $\begin{array}{l}\text { Fails to ask for assistance or } \\
\text { recognize a need for } \\
\text { additional help/guidance }\end{array}$ & $\begin{array}{l}\text { Recognizes opportunities to } \\
\text { improve knowledge by } \\
\text { asking questions and seeking } \\
\text { outside help; values feedback }\end{array}$ & $\begin{array}{l}\text { Takes an active role in learning } \\
\text { and seeks out mentoring and } \\
\text { active learning situations }\end{array}$ \\
\hline Time management & $\begin{array}{l}\text { Time is dedicated to low } \\
\text { priority tasks and deadlines } \\
\text { are often missed }\end{array}$ & $\begin{array}{l}\text { Use of time is based on the } \\
\text { greatest priority and tasks are } \\
\text { completed in a timely manner }\end{array}$ & $\begin{array}{l}\text { Tasks are completed early and } \\
\text { priorities are clearly } \\
\text { delineated }\end{array}$ \\
\hline Change adaptability & $\begin{array}{l}\text { Inability to self-motivate in } \\
\text { changing circumstances }\end{array}$ & $\begin{array}{l}\text { Recognizes change and takes } \\
\text { initiative to start necessary } \\
\text { tasks and redirect effort to } \\
\text { meet new priorities }\end{array}$ & $\begin{array}{l}\text { Adapts to change and embraces } \\
\text { opportunities to find new } \\
\text { challenges }\end{array}$ \\
\hline Professionalism & $\begin{array}{l}\text { Demonstrates a lack of maturity } \\
\text { or understanding of } \\
\text { professional standards }\end{array}$ & $\begin{array}{l}\text { Behavior, attitude, and } \\
\text { deliverables are produced in } \\
\text { accordance with basic } \\
\text { standards of professionalism }\end{array}$ & $\begin{array}{l}\text { Exceeds industry standards for } \\
\text { professional conduct and } \\
\text { serves as an example for } \\
\text { others }\end{array}$ \\
\hline
\end{tabular}

new ones, we integrate technical and career skills (as would be the case in jobs postgraduation), ensure multiple opportunities to hone and reinforce, and avoid increasing the number of required credit hours for graduation. Defining a target exit level of competency for each skill enables faculty to incorporate the skill directly into the course assessments, assuring the academic rigor of this component of student training (Tables 1-6). We have made the career skills and competency levels public to reinforce our commitment toward preparing 
Table 6. The University of Arizona College of Agriculture and Life Sciences [CALS (Tucson, AZ)] identified leadership/ management competencies "career skills" to incorporate into the CALS curriculum. The rubric identifies specific skills and competency levels to evaluate student proficiency in teamwork/collaboration skills.

\begin{tabular}{|c|c|c|c|}
\hline \multirow[b]{2}{*}{ Career skills } & \multicolumn{3}{|c|}{ Competency level } \\
\hline & Unacceptable & Exit & Advanced \\
\hline $\begin{array}{l}\text { Listen and respond } \\
\text { effectively }\end{array}$ & $\begin{array}{l}\text { Information flow one direction } \\
\text { with little understanding of } \\
\text { other individuals' points of } \\
\text { view }\end{array}$ & $\begin{array}{l}\text { Listens actively and } \\
\text { communicates to ensure } \\
\text { team members understand } \\
\text { alternate points of view }\end{array}$ & $\begin{array}{l}\text { Listens actively and effectively } \\
\text { uses written and verbal } \\
\text { communication to share } \\
\text { points of view and increase } \\
\text { understanding among all }\end{array}$ \\
\hline $\begin{array}{l}\text { Willing to engage and } \\
\text { make meaningful } \\
\text { contributions }\end{array}$ & $\begin{array}{l}\text { Serves as a distraction for the } \\
\text { team or refuses to engage }\end{array}$ & $\begin{array}{l}\text { Contributions to the team are } \\
\text { purposeful and productive; } \\
\text { "free riding" is minimized as } \\
\text { are tangential distractions }\end{array}$ & $\begin{array}{l}\text { Engages all team members with } \\
\text { thoughtful and persuasive } \\
\text { contributions that lead to } \\
\text { a meaningful outcome }\end{array}$ \\
\hline
\end{tabular}

students for a successful professional life after graduation, and to invite feedback from our employer partners.

We want students to have the opportunity to gain experience in career skills in many different ways, both inside and outside of the classroom. Not every course, club, or activity must cover all of these competencies, but the grand design is that students will have opportunities over their college career to achieve all of these competencies. To help toward this end, we have developed three leadership programs in CALS (Peer Mentors, Deans Leadership 50, and Ambassadors). However, we recognize that such programs only reach a small percentage of our students (perhaps 100 out of more than 3000 undergraduates). The curriculum-based career skills/competency approach we are using is unique in that we will reach all students in our college with this training, and thereby, we will give our students "a competitive advantage" as they advance their careers with our agency, industry, and graduate and professional program partners.

\section{Literature cited}

Chamorro-Premuzic, T., A. Arteche, A.J. Bremner, C. Greven, and A. Furnham. 2010. Soft skills in higher education: Importance and improvement ratings as a function of individual differences and academic performance. Educ. Psychol. Intl. J. Expt. Educ. Psychol. 30:221-241.

Evers, F.T., J.C. Rush, and I. Berdrow. 1998. The bases of competence: Skills for lifelong learning and employability. Jossey-Bass, San Francisco, CA.
Grugulis, I. and S. Vincent. 2009. Whose skill is it anyway? 'Soft' skills and polarization. Work Employ. Soc. 23:597-615.

Hurrell, S.A., D. Scholarios, and P. Thompson. 2012. More than a "Humpty Dumpty" term: Strengthening the conceptualization of soft skills. Econ. Ind. Democracy 34:161-182.

Matteson, M.L., L. Anderson, and C. Boyden. 2016. "Soft skills": A phrase in search of meaning. Libraries Acad. 16:7188 .

Robles, M.M. 2012. Executive perceptions of the top 10 soft skills needed in today's workplace. Bus. Commun. Q. $75: 453-465$.

Zhang, A. 2012. Peer assessment of soft skills and hard skills. J. Info. Tech. Educ. Res. 111:155-168. 